\title{
Article Review - Social Presence within the Community of Inquiry Framework
}

At the outset, I want to thank David Annand (2011) for his interest in the community of inquiry (CoI) theoretical framework. We welcome all constructive efforts to address its validity and give direction to future study. Moreover, Annand is quite right to address the validity and function of the social presence (SP) construct. I have stated previously "there is much to understand with regard to the construct itself and its relationship to the other presences" (Garrison, 2011, p.35). While there is need of research into this construct, I do not agree with Annand that the CoI framework "does not adequately inform the development of online education theory and practice” (p. 40), and, specifically, that the influence of social presence (SP) is overstated. I argue that much work remains in refining and understanding SP within the CoI framework but that it is an essential construct in a collaborative constructive approach to learning.

Perhaps not surprisingly, I do not agree with David's analysis and interpretation of the studies he has raised. The core problem I wish to focus on here is that we have two very different perspectives. I believe David's critique goes off-track at the outset by not recognizing the paradigmatic assumptions of the CoI framework and the educational purposes and contexts to which it is intended to address. For example, David states that "careful reading" of the research indicates "that students do not attach much value to the group-based influences of social presence" (p. 41). This is certainly true when the learning activities are focused largely on information transmission. In such contexts there is little reason or incentive to engage in collaborative inquiry.

It would seem to me that this critique appears to be coming largely from a distance education perspective, which is very different from the online learning perspective that is the gen- 
esis of the CoI framework (Garrison, 2011; Guri-Rosenblit \& Gros, 2011). The differences in pedagogical perspectives (generations) and the usefulness of the CoI framework in understanding these differences has been rigorously made by Anderson and Dron (2011). The reality is that the CoI theoretical framework with its collaborative constructivist perspective is essentially incompatible with traditional distance education approaches that value independence and autonomy over collaborative discourse in purposeful communities of inquiry (Garrison, 2009). In short, the explanatory value of a CoI approach depends on the educational purpose and context. In this regard, it is important not to conflate two distinct educational paradigms.

The intent of this space does not permit a full defense of a collaborative constructivist approach, a counter-interpretation of selected studies, or a discussion of studies that do confirm the important mediating function of SP in a CoI (this is explored in some detail in Garrison, 2011). However, the literature around critical thinking does provide the evidence that it is very difficult to achieve deep understanding without discourse. While this may be accomplished through Socratic dialogue or in a one-to-one tutorial with a qualified instructor, it is totally impractical in most educational contexts (especially scalable distance education). The CoI theoretical framework is a commitment to personal reflection and critical discourse (both are inherent to the CoI framework and the cognitive presence construct). Discounting SP is to discount the importance of critical discourse in a connected, knowledge-based society. It is also difficult to see how one gains metacognitive awareness and ability without sustained discourse and feedback (Akyol \& Garrison, 2011). This may well be one of the great weaknesses of independent study and didactic approaches.

The CoI is a generic theoretical framework that must be viewed as a means to study collaborative constructivist educational transactions - be they in online, blended, or faceto-face environments. The validation of this framework would also suggest that it can be used as a rubric to test for functioning communities of inquiry. The bottom line is that it is misleading and counter-productive to critique a framework from an incompatible paradigmatic perspective that is not congruent with a context or for a purpose for which it was not intended. Analogically we would never consider mapping a basketball framework onto tennis. While both are sporting events, their assumptions and activities are distinct. The same could be said of the assumptions and activities of independent and collaborative approaches to educational experiences. Both may be considered educational, but they are two very different games.

Certainly I have a different interpretation of most of the studies cited by Annand. I think one of the main problems with CoI research is the tendency to consider every online/blended learning environment is a true community of inquiry design when, in fact, there is little teaching, cognitive, or social presence (students are reliant on independent activities and tests). Most practical applications are imperfect designs and we should expect some ambiguity. Regardless, theoretically and practically there is much evidence for the mediating function of social presence in the studies cited by Annand as well as others not cited. Notwithstanding this, the categories of SP are open to refinement but are not necessarily compatible with independent (or informal) learning activities and should not be critiqued 
from this perspective. In terms of refinement, I have offered a revised definition of SP "as the ability of participants to identify with the group or course of study, communicate purposefully in a trusting environment, and develop personal and affective relationships progressively by way of projecting their individual personalities" (Garrison, 2011, p. 34). The intent of this revised construct was to show the development of SP as well as clarify its interdependence with cognitive and teaching presence.

However, much work remains to refine this and the other presences to understand collaborative constructivist approaches to educational transactions. In this regard, let me add one final point about future CoI studies. That is, empirical validation of the CoI framework is not antithetical to a collaborative constructivist approach as Annand seems to suggest when he states that "the CoI framework has evolved from a description of the learning process in a social constructivist paradigm to an empirically testable construct within an objectivist paradigm" (p. 49). The rationale for this statement escapes me.

In summary, I believe the CoI framework has mistakenly gotten caught in the middle of a higher order philosophical and methodological conflict. This critique seems to be more of an argument for independent study (an objectivist paradigm) and against a collaborative, cohort-based approach (a constructivist paradigm) than it is a valid critique of the CoI theoretical framework. This is a fundamental understanding essential in refining the CoI theoretical framework as we move forward.

\section{References}

Akyol, Z., \& Garrison, D. R. (2011). Assessing metacognition in an online community of inquiry. Internet \& Higher Education, 14(3), 183-190.

Anderson, T, \& Dron, J. (2011). Three generations of distance education pedagogy. International Review of Research in Open and Distance Learning, 12(3), 80-97. Retrieved from http://www.irrodl.org/index.php/irrodl/article/view/890/1663

Annand, D. (2011). Social presence within the community of inquiry framework. International Review of Research in Open and Distance Learning, 12(5), 38-54. Retrieved from http://www.irrodl.org/index.php/irrodl/article/view/924/1855

Garrison, D. R. (2009). Implications of online learning for the conceptual development and practice of distance education. Journal of Distance Education, 23(2), 93-104.

Garrison, D. R. (2011). E-Learning in the 21st century: A framework for research and practice (2nd ed.). London: Routledge/Taylor and Francis.

Guri-Rosenblit, S. \& Gros, B. (2011). E-Learning: Confusing terminology, research gaps and inherent challenges. Journal of Distance Education, 25(1). Retrieved from http:// www.jofde.ca/index.php/jde/article/view/729 
Athabasca University $\mathbf{I}$

(c) $\underset{\mathrm{EY}}{\mathrm{C}}$ 